\title{
Australian-American relations in the new century: applying resuscitation or pursuing illusions?
}

\author{
William T. Tow
}

More than a decade after the end of the Cold War and with Australian forces set to embark upon a major military intervention in the Persian Gulf along with their American and British counterparts in early 2003, it is appropriate to measure how effective the Howard government has been in 'resuscitating' the US alliance-its core foreign policy commitment since taking office in early 1996 (Liberal/National Parties 1996). The Australia-New Zealand-United States alliance, or ANZUS, as it was originally designated, was drafted and signed in September 1951. New Zealand, the third founding member of the original agreement, was extricated from the alliance in 1986 due to its anti-nuclear stance. The first year of the George W. Bush Ir administration was marked by both American security officials and their Australian counterparts lauding the 50th anniversary of that alliance (Powell et al. 2001; Reith 2001). Subsequently, the identity and credibility of that alliance has been tested by the global war on terrorism and by the Bush administration's tendency to promote alliance loyalty as the major basis for sustaining security ties with Australia. Prime Minister Howard largely complied with President Bush's expectations but, in doing so, may have tested Australian public support for Australian-American strategic collaboration more than any other Australian leader in recent times (Kelly 2003).

The story of ANZUS over the past decade has been how Australian and American defence planners have interpreted and adjusted to immense and ongoing structural change in international relations. Australia shifted from a Cold War posture of 'forward defence', anticipating its forces fighting alongside major allies in distant Asian locales against ideological adversaries, to one emphasizing 
'defence self-reliance', demanding flexibility in strategic planning in a less strategically predictable region. Throughout 2002 and early 2003, however, Australia's strategic posture was adjusted to emphasize Australian Defence Force (ADF) involvement in American-led coalition operations further afield, and to move toward greater and more flexible force mobility (Department of Defence 2003). The threat of international terrorism had become the most compelling factor in Australia's strategic thinking.

Yet pressing regional security challenges loomed precipitously, a condition acknowledged by official policy statements (Department of Foreign Affairs and Trade 2003a; Department of Defence 2003). Disruption of Northeast Asia's great industrial economies, endemic fragmentation of Southeast Asian polities and instability in the 'inner arc' from East Timor through Papua New Guinea to the Melanesian islands were all potential contingencies. In the rapidly evolving AsiaPacific security environment, the American alliance still represented a fundamentally welcome strategic hedge for Australia, as that accord is underwritten by fundamentally shared values and interests. Questions were increasingly raised, however, over the extent to which the Howard government's perceived tendency to over-emphasize alliance loyalty enhanced or undercut Australia's international standing in the eyes of many regional and international elites who opposed American military intervention against Saddam Hussein and feared what they regarded to be the intensification of American unilateralism.

US strategists, no less than their Australian counterparts, are confronted with global structural changes that demand new strategic thinking. Even before September 11, the Bush administration had argued that the global threat environment confronting the United States is far more fluid and uncertain, involving such 'new' concepts as homeland defence, area denial, anti-access, and surge capabilities (Powell et al. 2001; Krepinovich, 2001). Following the terrorist strikes against New York and Washington, it has insisted that the United States is moving into an era where the American homeland will be vulnerable to not only international terrorism, but to other threats. It has defined these as emanating from both hostile state-centric power centres (i.e. Iraq, Iran and North Korea) and substate terrorist organizations hostile to the United States capable of launching nuclear strikes or employing other weapons of mass destruction (WMD) against US targets. In September 2002, Bush announced a new American National Security Strategy that focused on 'preemption'-_eliminating potential adversaries' WMD capabilities - in lieu of traditional postures of deterrence and containment (Bush 2002).

The Bush administration reasons that allies such as Australia are expected by Washington to supplement American force planning in meeting these threats. The American journalist Thomas Friedman has even argued that the 'old NATO' will likely be replaced as a military alliance of three like-minded English-speaking maritime allies - the United States, Britain and Australia-that can project mobile forces over long distances to fight limited conflicts on behalf of democratic nations 
(Friedman 2002). Australia will also likely be viewed as a key participant with the United States in integrating existing US defence relationships in the Asia-Pacific with existing multilateral arrangements in the region, including the ASEAN Regional Forum (the ARF) or the Asia-Pacific Economic Cooperation (APEC) group (Blair 2001; Tow 2001). Because Australia's natural geographic purview lies within the Asia-Pacific, Australian-American defence relations may well revert to a predominantly regional context over the longer term, combining bilateral alliance features such as force interoperability and logistical coordination with regional coalition operations such as peacekeeping in East Timor and patrolling Southeast Asia's littorals.

This chapter assesses the prospects for the Australian-American alliance to realize an identity that strikes a judicious balance between regional and global geopolitical imperatives. Initially, Australia's strategic identity as it is shaped by the need to calibrate its American alliance with its quest to be accepted by its Asian neighbours will be briefly reviewed. How attaining that balance may become more complicated by the Bush administration's evident insistence to focus on a relatively 'unilateralist' concept of national interest will then be discussed. Finally, the need to avert alliance policy disunity over Iraq, North Korea and a more powerful China will be evaluated. If not managed carefully, these factors could strain alliance relations. The probability of alliance dissolution remains small. But the stakes in avoiding this possibility are so great as to merit analysis of what could go wrong in order to avoid any such contingency.

\section{Australia's regional security 'identity'}

International relations theorists have recently focused on how perceptions of 'otherness' complicate politico-security issues between people and states (Wendt 1999; Campbell 1998). Various analysts concerned about Australia's regional security identity have referred to these perceptions in advocating a 'reconstruction' of Australia's 'profile' to one more compatible with Asian cultures (Fitzgerald 1997; Dalby 1996). Other observers note that post-Cold War security politics have led to Australia becoming a 'torn country', caught between western and Asian civilizations. This school of thought argues that Australia's future wealth and security could be better realized if it adopted a 'Pacific power' identity by developing intensified ties with the United States as 'the leading power within western civilization' (Huntington 1996). The former perspective coincides, at least in part, with the regional engagement strategy of the Hawke/Keating governments; the latter approach could be equated to the Howard government's geopolitical preferences (McDougall 1998). Both strategies are predicated on a regionally active American ally underwriting Australia's search for 'the right balance' between alliance maintenance and cultivating more extensive and deeper Asian ties. But their differences underscore an implicit recognition within Australia's wider body politic that the country's long-term role in the Asia-Pacific has yet to be precisely defined or implemented with total clarity. 
Some consensus about Australia's regional security role appeared to be emerging by the end of the $1990 \mathrm{~s}$. Australia's Coalition government preceded preparation of its 2000 Defence White Paper by conducting an extensive public review of defence policy (Department of Defence 2000). The outcome was general public support for a substantial increase in defence outlays over the ensuing decade, and a national security approach that was largely accepted in most political quarters as a prudent and forward-looking strategic posture appropriate to Australia's regional environment and circumstances.

Following the September 11 attacks, however, what bipartisanship that may have existed between Australia's major parties was shattered. A widening gap developed between the Coalition government and the Labor Party opposition over how Australia should best respond to the new international security environment. Impelled by its prime minister's presence in Washington during the terrorist attacks, the Australian government quickly activated Article IV of the ANZUS Treaty to signal its involvement in the Bush administration's global war on terrorism (White House 2001). The image of an Australia under siege from terrorist threats was further intensified by the bombing of its citizens at two nightclubs in Bali during early October 2002 and by Howard's subsequent observation that any Australian Prime Minister would need to consider pre-emptive strikes in neighbouring countries harbouring terrorist threats (Burton 2002). The Prime Minister refused to back away from this position, notwithstanding the visible condemnation it generated among Southeast Asian policy elites, hardening their already strong perceptions that Australia was assuming the role of a "deputy sheriff' in the Asia-Pacific to enforce US strategic interests. In subsequent meetings with their US counterparts, moreover, the Australian foreign and defence ministers postulated the imperative for Southeast Asian states to collaborate with Australia and the United States to defeat terrorism and justified Australia's support for President Bush's projected military intervention against Iraq (Washington File 2002).

Australia's Labor Party, acting in the role of the country's major political opposition, served notice that it had serious concerns about the United States becoming more inclined than previously to adopt unilateral approaches and asserted that Australia's national interests may not always coincide with US policy (Crean 2003). It further posited that where Australia disagrees with the United States on the latter's policies toward the environment, China, trade, or other issues it should do so openly and honestly while still keeping the overall importance of the alliance central to its policy calculations. To offer any less than well considered dissent when US interests and policies appear to be clearly at odds with Australia's own and with those of other US regional friends and allies, it argued, would be more sycophantic than strategically constructive from both the Australian and American vantage points (Brereton 2001). Labor's calculation is that the Australian-American alliance is sufficiently pliable and robust to accommodate intermittent and sincere differences of opinion. 
Increasing alliance strains in the absence of an obvious mutual threat hardly surprise classical alliance theorists who warn that any security cooperation arrangement remains viable only so long as its affiliates' national interests are compatible. Indeed, Labor Party leader Simon Crean found himself caught between anti-war factions within his own ranks and an American administration increasingly concerned about Labor's propensity to support the American alliance. His efforts to steer a middle course by tying his own support for yet another Persian Gulf conflict to the United Nations' endorsement that was clearly not forthcoming and to the primacy of Australia's regional security environment failed to translate into domestic political gains. By early March 2003, Labor's pleas to focus more on regional security appeared to be increasingly prescient, however, as North Korea's erratic strategic behaviour affected the Howard government's evolving defence strategy. Possible Australian involvement in future regional missile defence initiatives drew warnings from Labor spokespersons and from Chinese officials that an extensive Asia-Pacific arms race would be the primary byproduct of an anti-North Korea initiative (Australian Broadcasting Corporation 2003; Davis 2003).

Australians are becoming more uncertain over their country's future regional identity. They ponder their country's ability to manage the emerging security challenges posited by a divided Indonesia, a diplomatically moribund Southeast Asia, a turbulent South Pacific, an increasingly volatile Korean peninsula, and a China growing strong. Confronting these problems will require levels of diplomatic skill, economic viability and strategic influence that may be beyond Australia's current capacity to project because it is regarded as too dependent upon American prosperity and military power. Critics cite Australia's failure to gain membership in the ASEAN +3 grouping, and its dependence on US military technology and logistics, as examples of the costs of its close association with America (Brown and Rayner, 2001). China and various ASEAN states remain unconvinced that Australia is actually prepared to reconcile its geography with its past culture and history.

Southeast Asian states still tend to view their security relations with both Australia and the United States in an ambiguous, even inconsistent, way. This renders the 'identity issue' less critical to regional alliance politics than might otherwise be the case. Most ASEAN states do not view ANZUS as a distinct security entity directly related to their own region, and most have appreciated that security pact's role in maintaining a US security presence in their neighbourhood (Anwar 2001). Nevertheless, Australian 'values' which appear too closely aligned with American or western norms threaten to isolate Australia from Southeast Asia.

The unfortunate (if inaccurate) 'deputy sheriff' perception of the Australian-led intervention in East Timor during late 1999 is a case-in-point (Baker and Paal 2000; Dupont 2000). Efforts by the American delegation at the 2001 AustraliaUnited States Ministerial (AUSMIN) meeting to defuse that image of Australia that had been disseminated by the Asian media only confirmed how seriously 
Australia's standing in the Asia-Pacific was challenged. A sequence of unrelated developments had already reinforced Australia's identity problem with Asians in this regard. Pauline Hanson's anti-immigration arguments in rural Australia and the Howard government's rejection of UN criticism over Australia's refugee policies alienated many Asian elites as they perceived, however inaccurately, a resurgence of 'White Australia' sentiment. Australia's escape from the most serious ramifications of the Asian financial crisis, and the Australian government and media subsequently and properly extolling this fact, was seen as self-appointed triumphalism in at least some Asian circles. Indonesia's cancellation of its bilateral security agreement with Australia during the East Timor crisis' intensification was an expression of Jakarta's frustrations, and a graphic illustration of Australia's identity problem in the region.

Australian observers less attuned or sympathetic to Asian temperaments might well conclude that such instances merely expose the inadequacy of various political norms and institutions in the region to face and resolve successive crises. Yet there is a danger that both Australia and the United States may focus too much on Asian states' paralysis in moving toward those values and strategic outcomes Australians and Americans would prefer at the expense of ascertaining how those states' strategic perceptions and priorities may be modified to coincide with alliance interests.

\section{American unilateralism}

During his presidential campaign, George W. Bush argued that if the United States remains a humble nation, but strong, the world would welcome it as standing alone in terms of world power even if it promoted a version of 'international freedom' that may not be welcomed by its competitors or even always by its friends (Bush 2000). Very soon after assuming the presidency, Bush found this proposition to be tested sharply with the United States rejecting the Kyoto treaty on carbon dioxide omissions, opposing the International Court of Justice, ignoring allied apprehensions over missile defences, failing to support international regulations for limiting small arms trade and withholding its support for a protocol at the biological weapons convention. By August 2001, European public opinion polls demonstrated high levels of dissatisfaction with the Bush administration's style of global diplomacy (Knowiton, 2001).

The intensification of the Iraq crisis in early 2003 further divided the United States and Europe, with long-time NATO allies France and Germany joining Russia to oppose the American, British and Australian use of force against Saddam Hussein. By early March, US policy officials were speculating openly about the United Nations Security Council's 'future relevance' while much of Europe was divided sharply over the extent to which the Bush administration was pursuing a unilateralist brand of geopolitics that threatened to push the world to the brink of conflict in the Middle East and beyond. In Asia, Japanese policy-makers remained supportive of US policies, especially as North Korea moved toward restoring its 
nuclear weapons production capabilities. But South Korea's leadership, including newly elected President Roh Moo-hyun, became increasingly concerned over President Bush's refusal to negotiate directly with a North Korean regime that appeared genuinely concerned that it would follow Iraq as a target of the American drive to neutralize so-called 'rogue states' (French 2003).

These trends reflected a fairly consistent adherence by the Bush administration to the politics of national interest over that of international community-building. Under its tutelage, the United States would act on the basis of pursuing a strictly defined set of national security imperatives rather than defer to a broad mantra of humanitarian values or institutional prerogatives. It would not dictate to other countries but would not hesitate to dissent from the wider 'international community' if it believed its vital interests were being undermined by complying with international obligations, or by those international commitments that may require that the sovereign rights of the American electorate be moderated (Rice 2000). Critics assert that neither American vital interests nor the threats that could have specifically undermine them has been defined by President Bush or his advisers very consistently or very systematically (Dewar 2001; Klurfield 2001).

American defence planning has been a major focus of concern in this context. During the first half of 2001, the Pentagon's quest to redefine American national security interests and priorities oscillated between the promise of strategic innovation and the quagmire of factional strife. President Bush and his Secretary of Defense, Donald Rumsfeld, entered office in January of that year pledging to fashion a new 'structural framework' for overall US global strategy and force configuration. Bush's new defence team argued that the Clinton administration had lost sight of America's core security needs and requirements in its efforts to apply US power to resolve a plethora of humanitarian crisis (Rice 2000). Less than six months after taking office Rumsfeld was at odds with most of his military chiefs over force priorities and expenditures, while his president slashed available financial resources for new defence programs by engineering a massive tax cut for the American electorate. An ongoing Quadrennial Defense Review became mired in inter-service rivalries and Congressional oversight, with such programs as missile defence, force restructuring and information warfare subject to rigid scrutiny by those elements of the US policy community who felt that they were initially excluded from the early days of the new administration's strategic deliberations (Shanker 2001).

The aforementioned National Security Strategy, with its emphasis on preemption against WMD threats, dovetailed with Australia's reassessment of its national security approach in the aftermath of September 11. As the United States was reorienting its strategic posture to preclude attacks against the American homeland, Australia was moving away from structuring its forces to defend against a conventional military attack. Strategic terrorism, WMD proliferation and growing regional instability were assigned higher priority, and future ADF deployments were projected to be part of a coalition global power projection led by 
the United States (Department of Defence 2003). This correlated neatly with the American pre-emption doctrine but questions remained how Australia's future force configuration would be tailored - and paid for--to fulfil the new alliance agenda (Allard, 2003; Barker 2003; Dupont 2003).

These developments have combined to form a void that, if left unfilled, could test the fabric of the Australian-American alliance. The United States appears to be out of step with many of its traditional friends and allies' expectations on how it should lead the world. To date, Australia has remained a conspicuous exception to this emerging alienation.

Against this backdrop, it may be useful to focus on two key components of the Bush administration's prospective approach to Asia-Pacific security as they relate to Australian-American relations: first, prospects for Australia reaching a free trade agreement with the United States as a balance for Australia's possible exclusion as a full-fledged regional player in Asian economic institutions and arrangements; and second, the danger of alliance policy disunity over how a stronger China should be managed relative to both Australian and American national interests. These questions are important empirical issues that will test Australian-American alliance relations if the Bush administration continues along its current unilateralist course, and as Australia confronts the need for it to reconcile its alliance agenda with the vagaries of regional geopolitics.

\section{Free trade as geopolitics}

Much has been written about the financial implications of the Asian financial crisis but the longer term geopolitical implications of that event have remained underassessed (Dibb, Hale and Prince 1999). Four years after the event, the vulnerabilities that precipitated that crisis are still largely unresolved and Asian elites have become more inclined to adopt policies of exclusion for organizing and safeguarding regional prosperity and security. The emergence of ASEAN +3 , for example, appears to be a rejection of the 'open regionalism' trading model supported by Australia and the United States through APEC in favour of one that embraces the theme of 'Asia for Asians' in the areas of trade and financing. Australia, in particular, appears to be isolated from membership in this new grouping by those in the region who argue that its credentials to be regarded as a genuine regional economic and strategic partner are suspect and that it would merely act as a US proxy if granted entry. They have pointed to Australia's initial opposition to an Asian Monetary Fund proposal advanced in 1997 by Japan, and to what they believe was a premature drive to link the ASEAN Free Trade Area (AFTA) with the Closer Economic Relations (CER) arrangement between Australia and New Zealand (Dodd 2000; Ghazali 2001).

The Howard government has admitted that Australia would eventually like to join ASEAN + 3 but has also recognized that its prospects for doing so in the near future are remote (Calvert 2000; Downer 2001). Australia is faced with the perception that it does not share the cultural affinity that unites East Asian states 
against an international financial sector they believe is led by the United States and the International Monetary Fund (IMF) and that discriminates against their own methods of economic management. As a result, Australia has begun shifting away from any commitment to secure export markets through multilateral agreements, and toward enhancing its trading position through bilateral negotiations with individual countries. Decreasing prospects for a new round of World Trade Organization (WTO) trade negotiations have further strengthened the appeal of bilateralism as a means for Australia to pursue trade gains and to break out from its intensifying sense of geopolitical isolation in the region. Within Asia, Singapore and Thailand both appeared to dissent from ASEAN's majority posture of opposing closer AFTA-CER economic links and both moved to initiate bilateral free trade ties with Canberra. Singapore's relatively open, service-oriented economy offers many compatibilities to Australia's own and a bilateral free trade accord was indeed signed between these two countries in February 2003 (Department of Foreign Affairs and Trade 2003b). Thailand views its security cooperation with Australia in regional peacekeeping as a natural basis for creating 'spillover' in areas of economic collaboration (Sheridan 2001a).

The major prize of any such bilateral strategy for Australia, however, would be to reach a free trade agreement with the United States. Much speculation has appeared in the Australian press about the Howard government's determination to lay the groundwork for such cooperation and about the favourable inclination of the Bush administration and key members of the US Congress for Australia to realize this objective. Negotiations on free trade were formally announced in November 2002 by US Trade Representative Robert B. Zoellick with the objective of reaching an agreement sometime during 2004. Australia's Labor Party has been generally supportive of the concept, but insists that a future Labor government would need to review any understandings reached with the Americans by Australia's current leaders (Kelly 2001; Office of the United States Trade Representative 2002).

There are clear advantages for both Australia and the United States in reaching such an accord. It would accelerate what is already Australia's second most important trading relationship (after Japan) and give it access to an American market that already has surpassed Japan to constitute Australia's top service export customer with 15.1 per cent of total exports (Department of Foreign Affairs and Trade 2003a, 144). A free trade agreement could lay the groundwork for the removal of American trade barriers against key Australian agricultural products (dairy products and sugar in particular) and increase prospects that American agricultural subsidy programs directed against the European Union would not be targeted against Australian farmers as well. It could eradicate long-standing US barriers against Australian textiles and transport products (such as catamaran ferries, where Australia remains a world leader). One recent Australian study commissioned by the Department of Foreign Affairs and Trade estimates that a bilateral free trade agreement unencumbered by 'exceptions' would increase 
Australia's total trade volume by almost $\$$ A4 billion by the year 2010 (Berkelmans et al. 2001). An Australian-American Free Trade Agreement could also breathe new life into multilateral trade politics, reinvigorating APEC through the United States negotiating similar accords with Singapore, Vietnam, New Zealand and South Korea. This pattern would undercut moves by other Asian economies to form trade blocs as an alternative to APEC's trade liberalization agenda. Australia would also be better cushioned from the impact of any Free Trade Area of the Americas (FTAA) that could form as an expansion of the North American Free Trade Agreement (NAFTA).

Posited against these rationales for pursuing a Free Trade Agreement is the risk of dashed expectations in the trade sector spilling over to affect security ties. Irritants in Australian-US trade relations continue to belie cheerful government media releases and sensational headlines promising instant gratification in this policy sector. The Bush administration instituted an appeal against the World Trade Organization's finding on lamb tariffs, which benefited Australian and New Zealand agricultural exports, with a letter written by Zoellick-otherwise regarded one of the most forceful advocates of an FTA. The longer term problem, however, looms in the US Congress where President Bush confronts the same type of resistance that confronted Bill Clinton in granting the chief executive fast-track trade legislation (or 'Trade Promotion Authority' as it has been redesignated by the Bush administration). Such legislation would allow the president to negotiate an agreement with Australia that could then be presented to Congress as a package to be accepted or rejected in its entirety. Under these circumstances that body would no longer have the ability to attach protectionist amendments to the legislation. Without such a constraint, Congress would not find it difficult to modify any trade liberalization initiatives in the interest of satisfying the economic interests of local and diverse agricultural constituencies. Even so, Australia's trading interests, which constitute only a minor blip on the American global trading radar screen (Australia takes in only about 1.6 per cent of US exports and accounts for a miniscule 0.7 per cent of its imports), could be readily subsumed by the Bush administration's preoccupation with developing trade in the United States' own hemisphere. The already substantial trade imbalance between the two allies, which favours the United States, could become a lightning rod for Australian national humiliation, and a basis for future Australian governments reassessing how the overall American relationship relates to the Australian national interest (Brenchley 2001).

\section{The China factor}

China represents the most daunting long-term regional security challenge for the Bush administration and a potentially divisive issue for the Australian-American relationship (Tow and Hay 2001). Although North Korea's nuclear behaviour perhaps constitutes the most immediate threat to regional stability, how China responds to Pyongyang's idiosyncratic postures will largely set the context for 
overall regional stability in the Asia-Pacific for years to come. The Korean nuclear question cannot be resolved without China applying its influence constructively to induce Kim Jong-il's North Korean regime to temper its strategic behaviour. Over the longer term, China's successful integration into the regional and international community as a peaceful and positive force for order and stability will be the most important component of Asia-Pacific security politics.

During his presidential campaign, Bush characterized China as America's 'strategic competitor'. In early April 2001, a US Navy EP-3 spy plane was involved in a mid-air collision with a Chinese fighter plane carrying out aggressive manoeuvres against the American aircraft, forcing it to make an emergency landing in Hainan. While both China and the United States exercised laudable strategic restraint in resolving that particular crisis, the ramifications of the incident were quickly felt by Australia. Two weeks after the EP-3 collision, two Australian guided-missile frigates and a supply ship were intercepted by a PLA naval patrol ship as they were sailing through the Taiwan Strait and directed to retreat from that location. Although the Australian ships ignored the PLA's demands, claiming the right of innocent passage through the strait, and proceeded without further challenge, this incident brought home to Australian policy planners that the ANZUS affiliation was regarded by their Chinese counterparts as an unwelcome element in what may be an intensifying long-term process of Sino-American strategic competition (Lague and Saywell 2001).

Since September 11, Sino-American tensions have dissipated in light of other crises preoccupying both Chinese and US policy planners. The Bush administration, in particular, has assumed a visibly more balanced position on relations with Beijing. Secretary of State Powell related to China's outgoing Ambassador to the United States in late January 2001, for example, that China was not viewed as America's 'inevitable foe', a message he repeated during his visit to Beijing in July. Yet other American policy factions, both within the Bush administration and in Congress, still entertain a hostile view. They wish the President to focus on the 'China threat' in terms of its rising military power, its hostility toward Taiwan and its suspect human rights record. They were particularly keen to capitalize on presidential candidate Bush's support for the Taiwan Security Enhancement Act (TSEA) that encouraged upgraded US military ties with Taipei (TSEA has not been passed into law). They also support the introduction of theatre missile defences to augment Taiwan's defence capabilities. While President Bush has thus far refrained from transferring such technology to Taiwan, he has directly linked Chinese behaviour in the Taiwan Strait with future propensity for such introduction (Mufson and Milbank 2001).

Those in both Australia and the United States who are concerned that the Bush administration may eventually lose control of the United States' 'China policy' point to several major concerns:

- The President's instincts are shaped by deeply conservative values that may gradually turn him into a hard-line China opponent if what he 
perceives as fundamental US national interests are tested too frequently by the Chinese;

- The Chinese have not and will not accept the missile defence rationales posited by the Bush administration. This will play into those within Beijing's leadership that are looking for 'an American enemy' to solidify their domestic political positions after the Chinese Communist Party's 16th Party Congress in 2002, where major leadership changes took place; and

- American unilateralism will not translate into the sophisticated US diplomacy needed to avert growing resentment by China, Russia and even Western Europe, and to affect a new global power balance predicated on a mutual recognition of each others' spheres of influence.

Recent informal discussions between Australian and American policy leaders have reinforced what has been a generally more positive reading of Sino-American relations. China's desperation to become a member of the WTO and to import western capital investment resulted in a softening of Chinese relations with Taiwan, moderating a Sino-American regional security dilemma that many previously regarded to be intractable. China's hosting of the 2008 Olympics was also viewed as a culmination of its government's long-standing quest to become 'legitimized' in the eyes of the international community. Speculation has even surfaced about America's willingness to sanction an eventual China-Taiwan reunification in return for a Chinese commitment to retract its current position on the right to use force, if need be, to re-assimilate Taiwan into the mainland (Kelly 2001).

There is little hard evidence, however, that China is radically transforming its long-standing apprehensions over American power and what that power means to Chinese interests. In mid-June 2001, a Sino-Russian summit convened in Shanghai, resulting in new agreement between Russia and China designed to counterbalance American global power and to consolidate international opposition to US missile defences (Elleman and Paine 2001). Sino-Russian collaboration also occurred in early 2003 against American and British efforts to secure a UN Security Council endorsement for military intervention against Iraq. The PLA continued to hold large wargames in the Taiwan Strait throughout this period of time as a clear signal to Taiwan not to provoke hostilities by pressuring the Americans to sell them more lethal defence assets. Chinese President Zhang Jimen is simultaneously projecting a posture of 'strategic warmth' toward the United States to preclude any inclination to transfer such weaponry to the Taiwanese; this can hardly be interpreted as Chinese capitulation to western agendas. China is proceeding to modernize its defences. It is converting its ground forces into smaller contingents with rapid deployment strike capabilities, and training them in jointforce manoeuvres and amphibious operations. It is upgrading its navy through purchases of Russian destroyers and frigates, and eliciting Moscow's assistance to modernize its nuclear submarine force. Russian surface-to-air missiles are being deployed to counter future American air or missile strikes that could otherwise 
neutralize Chinese regional warfighting capabilities or its few existing strategic missile systems. All of these preparations are designed to respond to contingencies that may emerge over years rather than in weeks or months. Yet all of them are directed toward achieving levels of power and capabilities that could seriously threaten Australian and American regional security interests in Asia's littorals and beyond (Joffe 2001).

In all candour, Australian and American policy planners know this and have been deliberating in alliance councils on ways that ANZUS can preserve an acceptable regional power balance. The idea of expanding AUSMIN consultations to include Japan reflects a classical power balancing approach. The timing of Secretary of State Powell's disclosure of such musings at the 2001 AUSMIN summit was unfortunate given that he had just visited Beijing. The logic underwriting such discussions, however, is understandable (Tow and Lyon 2001; Lim 2001). Until China is prepared to match its participation in global economic arrangements with a commensurate willingness to engage in restrained strategic behaviour, it will precipitate such responses among the United States and its two most important allies in the Asia-Pacific.

Both ANZUS allies should remember that Asia is not NATO. This is not merely attributable to the different histories and cultures of the two regions. It relates as well to the respective alliance systems. NATO is increasingly a "no threat' alliance, moving toward becoming a collective security organization. Russia resents potential US hegemony in Europe just as China challenges American power in Asia, but neither of these states currently confront or threaten the sovereignty or well being of other alliance members. However, where the Asian bilateral alliances differ from NATO is that they have no real collective security utility on their own but are primarily designed to rationalize a continued US power presence.

Intervention by the United States in a Sino-Taiwanese military confrontation would severely test ANZUS. Under such circumstances, Australians could reasonably ask themselves if their country's national interest would best be served by helping the Americans redress the policy miscalculations leading to such a Chinese provocation. If not, would Australia be willing to pay the price of incurring Washington's disillusionment or even its wrath by contesting the 'loyalty factor'? If Australia were to face the nightmare of a Sino-American war over Taiwan, and either Chinese pressure to abstain from that conflict or American demands to support a US intervention, it would confront a completely unacceptable dichotomy of risk that most alliances are designed to avoid. The founders of ANZUS might well be amazed that so many of their present-day counterparts on both sides of the Pacific believe that China is now inclined to modify its own core national interests to an extent that the allies' prospects for confronting such a risk are nil; hopefully, they are correct. 


\section{Conclusion}

As has been the case with every other modern American presidency, the Bush administration has confronted a steep learning curve in forging strategic policy around the world. Early speculation that this administration would be 'different' by making appointments and assigning priorities that are Asia-Pacific-sensitive must be treated with some scepticism. The United States remains, above all, a global power destined to approach problems and prioritize interests on an international scale rather on a region-centric basis. President Bush has been preoccupied with managing the issues of international terrorism and rogue states. In confronting serious European dissent to his unilateralist style, and mired in the quagmire of Middle Eastern conflict, he has sought and gained Australian support for his international security views and initiatives. The Asia-Pacific has hardly been ignored but it is still not given the level of attention that Australian policy-makers often believe should be allocated to it by their 'great and powerful [American] friend'. China, and, increasingly, North Korea, are the obvious exceptions to this pattern and their importance in any 'post-Saddam' international security milieu will clearly deepen.

Australia can best sustain the relevance of ANZUS by seeking tangible ways of balancing its alliance loyalty to the United States with its capacity to generate and implement independent diplomacy in Asia. It may well be that, with a successful conclusion to the Iraq quagmire, the Bush administration or its successors may yet become more attuned to the pragmatic dimensions of multilateral diplomacy and more sensitive to regional institutions' utility in promoting norms and interests that are conducive to both American and Australian influence in Asia. During the interim, Australia must take care not to represent bilateralism as more than what it is--a holding or hedging strategy to advance the interests of two close but hardly identical allies in an increasingly turbulent world until a better mutual understanding of the emerging international system is achieved.

The question remains as to how much policy damage American unilateralism and Australia's recent endorsement of it will inflict before the value of interdependence is recognized by both Canberra and Washington and is translated into modifying the American regional policy agenda. ANZUS cannot be perceived, regionally or internationally, as a mere default mechanism nurtured by a regional proxy of American power. Its fifty years of existence is better honoured by Australia being independent enough to dissent from its senior ally when such disagreement is appropriate, and to support it when common interests and values are truly at stake. Knowing when to support or dissent, and not shirking from the responsibility of doing so, constitutes the best guarantee for alliance preservation. 


\section{References}

Allard, Tom. 2003. 'Army Chief: More Funds Needed to Fight Terrorism', Sydney Morning Herald, February 28.

Anwar, Dewi Fortuna. 2001. 'A Southeast Asian Perspective' Australian Journal of International Affairs [ANZUS Special Issue] 55:2, pp. 213-23.

Australian Broadcasting Corporation, 2003. 'Beazely Slams Govt's Defence Strategy', February $27<$ http://www/abc.net.aw/lateline/s794630.htm $>$.

Baker, John and Douglas H. Paal. 2000, 'The US-Australia Alliance'. In Robert Blackwill and Paul Dibb (eds), America's Asian Alliances, Cambridge, MA: MIT Press, pp. $87-109$.

Barker, Geoffrey. 2003. 'It's Sensible to Engage in Missile Shield', Australian Financial Review, February 28.

Berkelmans, Leon, Davis, Lee, McKibbin Warwick and Stoeckel, Andrew. 2001. Economic Impacts of an Australia-United States Free Trade Area. Reprinted at $<$ http://www.dfat.gov,au/publications/aus us fta/index.html >.

Blair, Dennis C. 2001. Commander in Chief, US Pacific Command Media Roundtable, Canberra, Australia, July 31. Transcript reprinted at United States Pacific Command web site, <http://www.pacom.mil/speeches/sst2001/01073lblairaust.htm>.

Brenchley, Fred. 2001. 'Australia by George', The Bulletin, April, pp. 26-7.

Brereton, Laurie. 2001. 'United States Alliance (Media Statement)' 6 May as reprinted on the Australian Labor Party web site at $<$ http://www.alp.org.au/media/0501/ibmsus.060501.html $>$.

Brown, Gary and Laura Rayner. 2001. Upside, Downside: ANZUS After Fifty Years. Canberra: Parliamentary Research Service.

Burton, B. 2002. 'Howard Unmoved by "Pre-emption" Furor', Asia Times, 2 December at $<$ http://www.atimes.com>.

Bush, George W, 2000. 'On Internationalism' at $<$ http://www.issues2000org/Celb/George_W_Bush_Foreign_Policy.htm>.

Bush, George W. 2002. The National Security Strategy of the United States of America, Washington.

Calvert, Dr Ashton. 2000. 'Australia's Foreign and Trade Policy Agenda', Canberra, National Press Club, 3 August as reprinted at <http://www.dfat.gov.au/media/speeches/department/000803 html >.

Campbell, David. 1998. Writing Security: United States Foreign Policy and the Politics of Identity. Minneapolis: University of Minnesota Press.

Crean, S. 2003. "Work for Peace, Don't Plan for War--Countdown to War', The Australian, 5 February.

Dalby, Simon. 1996. ' Continent Adrift? Dissident Security Discourse and the Australian Political Imagination,' Australian Journal of International Affairs. 50:1, pp. 59-75.

Davis, Mark. 2003. 'China Riled by Howard Stand', Australian Financial Review, February 28.

Department of Defence. 2000. Defence Review 2000-Our Future Defence Force. Canberra: Defence Publishing Service. 
Department of Defence. 2003. Australia's National Security: A Defence Update 2003. Canberra: Defence Publishing Service.

Department of Foreign Affairs and Trade. 2003a. Advancing the National Interest. Canberra: Commonwealth of Australia.

Department of Foreign Affairs and Trade. 2003b. 'Singapore-Australia Free Trade Agreement (SAFTA)'

$<$ http://www.dfat.gov.au/trade/negotiations/australia_singapore_agreement. html>

Dewar, Helen. 2001. 'Another Democrat Escalates Criticism on Missile Defense and Kyoto', International Herald Tribune, 10 August.

Dibb, Paul, David D. Hale and Peter Prince. 1999. 'Asia's Insecurity', Survival 41:3, pp. 520.

Dodd, Tim. 2000. 'Australia Takes an Individual Approach to Asia', Australian Financial Review, 4 October, p. 11.

Downer, Alexander. 2001. 'Australia--Meeting Our International Challenges', Canberra, National Press Club, 1 March at $<$ http://www.dfat.gov.au/media/speeches/foreign/2001/010301_fa_npc.html >.

Dupont, Alan. 2000. 'ASEAN's Response to the East Timor Crisis', Australian Journal of International Affairs. 54:2, pp. 163-70.

Dupont, Alan. 2003. 'Straitjacket Off As Defence Gets Real' The Australian, February 27.

Elleman, Bruce and Paine, Sarah C.M. 2001. 'Security Pact With Russia Bolsters China's Power', International Herald Tribune, 6 August.

Fitzgerald, Stephen. 1997. Is Australia an Asian Country? St Leonards, NSW: Allen and Unwin.

French, Howard. 2003. 'North Korea crisis straining Washington's Asian Alliances', International Herald Tribune, February 25.

Friedman, Thomas. 2002. 'When Club NATO Turns Nasty, It's Attitude That Counts' Sydney Morning Herald, November 19.

Ghazali, Fadzil. 2001. "ASEAN Ministers Grapple with "CER" and "FTA", Business Times (Malaysia), October 9.

Huntington, Samuel. 1996. The Clash of Civilizations and the Remaking of World Order. New York: Simon and Schuster.

Joffe, Ellis. 2001. 'Don' $€$ Exaggerate the Military Threat from China', International Herald Tribune, July 28.

Kelly, Paul. 2001. 'China Turns On Charm', The Weekend Australian, August 18-19.

Kelly, Paul. 2003. 'Why PM Will Go All the Way' The Weekend Australian, February 1.

Klurfield, James. 2001. 'Bush Team Is Fumbling the Ball on Critical Foreign Policy Issues', Newsday, 12 July.

Knowlton, Brian. 2001، 'IHT Insight: Bush Gets Low Marks in Europe', International Herald Tribune, August 15.

Krepinovich, Andrew. 2001. Testimony before the Armed Services Committee, US House of Representatives, 20 June. reprinted at the Dow Jones Interactive web site at $<\mathrm{http} / /$ ptg.djur.com/ccroot/asp/publib/story.asp $>$.

Lague, David and Saywell, Trish. 2001. 'A Growing Storm for East Asia', Far Eastern Economic Review. 164:19, pp.16-21. 
Liberal/National Parties. 1996. 'A Confident Australia: Coalition Foreign Affairs Policy'. Melbourne, Vic: Printed and Authorized by L Crosby.

Lim, Robyn. 2001. 'Toward a New Security Architecture for East Asia', International Herald Tribune, 15 August.

McDougall, Derek. 1998. Australian Foreign Relations: Contemporary Perspectives. South Melbourne: Longman.

Mufson, Stephen and Milbank, Dana. 2001. 'Taiwan to Get Variety of Arms' Washington Post 24 April, as reprinted on the Taiwan Security Research web site at <http:/taiwansecurity.org/WP/2001/WP-043401.htm>.

Office of the United States Trade Representative, 2002. 'USTR Zoellick Notifies Congress of Intent to Initiate Free Trade Negotiations with Australia' at $<$ http://www.ustr.gov/releases/2002/11/02-110.htm>.

Powell, Colin L., Secretary of State, Secretary of Defense Donald H. Rumsfeld, Admiral Dennis C. Blair, Foreign Minister Alexander Downer, Minister of Defense Peter Reith, and Admiral Chris Barrie, 2001. Press Conference. Canberra Australia, July 30 at <AUSMIN 2001. http://usembassy-australia.state.gov/ausmin/jointpc.html>.

Reith, The Hon Peter, MP. 2001. 'The US-Australia Alliance in an East Asian Context', University of Sydney, June 20. At bttp://usembassy-australiastate,gov/anzus/reith_remarks.html.

Rice, Condoleezza. 2000. 'Promoting the National Interests', Foreign Affairs. 79:1, pp.4562.

Shanker, Thomas. 2001. 'Rumsfeld Sees Discord on Size of Military' The New York Times, July 19.

Sheridan, Greg. 2001a. 'Bangkok Wants to get Intimate', The Weekend Australian, 7-8 July.

Sheridan, Greg. 2001b. 'Leading the Field on US Free Trade Deal', The Weekend Australian, August 18-19.

Tow, William T. and Hay, Leisa. 2001. "Australia, the United States and a "China Growing Strong": Managing Conflict Avoidance' Australian Journal of International Affairs. 55:1, pp. 37-54.

Tow, William 'T, and Lyon, Rod. 2001. 'Everyone Loses in II-timed 'JANZUS Talks', The Age (Melbourne), 2 August.

Tow, William T. 2001. Asia-Pacific Strategic Relations: Seeking Convergent Security. Cambridge and South Melbourne; Cambridge University Press.

Washington File EPF302. 2002. 'Transcript: US, Australia Stand Together Against Terrorism', 30 October.

Wendt, Alexander. 1999. Social Theory of International Politics. New York; Cambridge University Press.

White House, Office of the Press Secretary. 2001. 'US-Australia Treaty Article IV Applies to Terrorist Attacks' at <http:/usinfo.state.gov/topical/pol/terror/01091501.htm>. 